\title{
Trace metal pollution in Umtata River
}

\author{
OS Fatoki ${ }^{1 *}, \mathrm{~N} \mathrm{Lujiza}^{1}$ and AO Ogunfowokan ${ }^{2}$ \\ ${ }^{1}$ Department of Chemistry, University of Fort Hare, Alice 5700, South Africa \\ ${ }^{2}$ Department of Chemistry, Obafemi Awolowo University, Ile Ife, Nigeria
}

\begin{abstract}
Dissolved trace metals, i.e $\mathrm{Fe}, \mathrm{Mn}, \mathrm{Al}, \mathrm{Cu}, \mathrm{Zn}, \mathrm{Pb}$ and $\mathrm{Cd}$ were determined in the Umtata River. High levels of $\mathrm{Al}, \mathrm{Cd}, \mathrm{Pb}, \mathrm{Zn}$ and $\mathrm{Cu}$ were observed, which may affect the "health" of the aquatic ecosystem. The high levels of $\mathrm{Al}, \mathrm{Cd}$ and $\mathrm{Pb}$ may also affect the health of the rural community that uses the river water directly for domestic use without treatment. Generally the sources of the metals in the river appear to be diffuse, which include rural, urban and agricultural runoff sources in the catchment, although there may be contributions from natural and point sources.
\end{abstract}

\section{Introduction}

The accumulation of metals in an aquatic environment has direct consequences to man and to the ecosystem. Interest in metals like $\mathrm{Zn}$ and $\mathrm{Cu}$ which are required for metabolic activity in organisms, lies in the narrow "window" between their essentiality and toxicity (Skidmore, 1964; Spear, 1981). Others like Al, Cd and Pb exhibit extreme toxicity even at trace levels (Merian, 1991; DWAF, 1996a-c).

The presence of $\mathrm{Al}$ in a natural water system is of major concern because of the potential threat to the health of a number of species including humans (Lewis, 1989; Radunovic and Bradbury, 1993). $\mathrm{Al}$ is known to be toxic to the central nervous system and plays a role in causing dialysis encelophathy and dialysis osteodystrophy (Alfery et al. 1976; Savory and Wills, 1991). Some lakes, rivers, groundwater and domestic tap waters contain Al in high concentrations either naturally (Al could be mobilised from soils and sediments by both natural weathering and accelerated acidification processes, resulting in detectable concentrations in surface waters) or because $\mathrm{Al}$ has been added as a flocculant in the purification process (DWAF, 1996b). The implication of this may be serious since Al ions have been demonstrated to be toxic especially to individuals with impaired renal function (Savory and Wills, 1991).

$\mathrm{Zn}, \mathrm{Cu}, \mathrm{Pb}$ and $\mathrm{Cd}$ are common pollutants, which are widely distributed, in the aquatic environment. Their sources are mainly from weathering of minerals and soils (Merian, 1991); atmospheric deposition (Merian, 1991); industrial effluents (Asami, 1974; Prater, 1975) domestic effluents (Dean et al., 1972; Preuss and Kollman, 1974), urban storm water runoff (Sartor et al., 1974; Field and Lager, 1975) and spoil heaps (Heitfield and Schottler, 1973).

Extensive literature on the aquatic toxicity of $\mathrm{Zn}$ and especially its toxicity to fishes has been reviewed by Alabaster and Lloyd (1980) and by Spear (1981). Zinc is unusual in that it has low toxicity to man, but relatively high toxicity to fish (Alabaster and Lloyd, 1980).

\footnotetext{
* To whom all correspondence should be addressed

Ifi 040 6022011; fax: 040 6531643; e-mail: OFatoki@ufh.ac.za Received 7 September 2001; accepted in revised form 2 January 2002.
}

Copper is one of several heavy metals that is essential to life despite being as inherently toxic as non-essential heavy metals exemplified by $\mathrm{Pb}$ and $\mathrm{Hg}$ (Scheinberg, 1991). Plants and animals rapidly accumulate it. It is toxic at very low concentration in water and is known to cause brain damage in mammals. (DWAF, 1996b).

Cadmium has been found to be toxic to fish and other aquatic organisms (Rao and Saxena, 1981; Woodworth and Pascoe, 1982). The effect of Cd toxicity in man includes kidney damage (Friberg, et al., 1986a; Herber et al., 1988) and pains in bones (Itai-itai disease) (Tsuchiya, 1978; Kjellstroem, 1986). Cd also has mutagenic, carcinogenic and teratogenic effects (Fischer, 1987; Friberg et al., 1986b, Kazantzis, 1987, Heinrich, 1988).

Lead is defined by the United States Environmental Protection Agency (USEPA) as potentially hazardous to most forms of life, and is considered toxic and relatively accessible to aquatic organisms (USEPA, 1986). Low $\mathrm{Pb}$ concentrations affect fish by causing the formation of coagulated mucous over the gills and subsequently over the entire body and thus cause the death of fish due to suffocation (DWAF, 1996b). Lead is bio-accumulated by benthic bacteria, freshwater plants, invertebrates and fish (DWAF, 1996b). The chronic effect of $\mathrm{Pb}$ on man includes neurological disorders, especially in the foetus and in children. This can lead to behavioral changes and impaired performance in IQ tests (Lansdown, 1986; Needleman, 1987). The major effect of the presence of $\mathrm{Fe}$ and $\mathrm{Mn}$ in domestic water is aesthetic because of the colour.

The $\mathrm{pH}$ of a water body determines the chemical species of many metals and thereby alters the availability and toxicity in the aquatic environment (DWAF, 1996b). Metals such as Al, Cd, Pb, $\mathrm{Cu}, \mathrm{Mn}$, and $\mathrm{Zn}$ are most likely to have increased detrimental environmental effects as a result of a lowered pH (DWAF, 1996b).

Lead absorption by aquatic organisms is dependent on the action of $\mathrm{Ca}$; therefore hardness is an important factor in determining the toxicity of $\mathrm{Pb}$ in the aquatic systems (DWAF, 1996b). Lethal concentrations of $\mathrm{Cd}$ also vary with water hardness and type of test animal. (DWAF, 1996b).

This study reports the levels of dissolved $\mathrm{Al}, \mathrm{Cd}, \mathrm{Zn}, \mathrm{Cu}, \mathrm{Pb}, \mathrm{Fe}$ and $\mathrm{Mn}$ in the Umtata River and the associated $\mathrm{pH}$ and total hardness values of the water body. This catchment supports a rapidly growing population and there are concerns regarding the water quality of the river. The main uses of water in the catchment are domestic, agricultural (i.e. livestock watering), aquatic ecosystem use and recreational (e.g. swimming). Water from the Umtata River is rarely used for irrigation. 


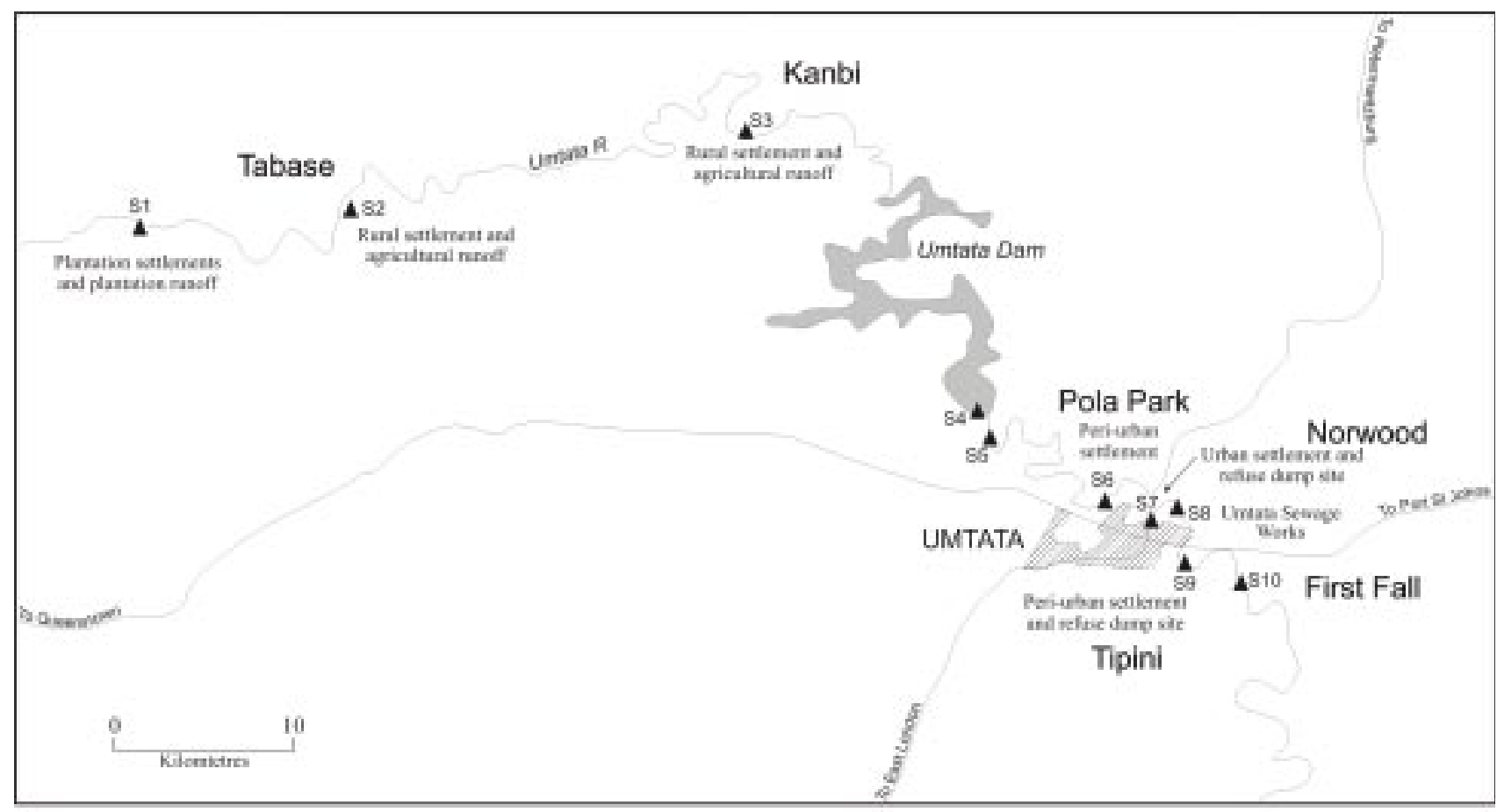

Figure 1

Map of the sampling sites

\section{Description of the river catchment}

The Umtata River rises in the plateau region of the Eastern Cape province of South Africa, approximately midway between the Drakensburg escarpment and the Indian Ocean (Fig. 1). The catchment of the river itself is some $100 \mathrm{~km}$ long and up to $50 \mathrm{~km}$ in width. The main tributary of the Umtata River is the Ngqungqu River that enters the main river on the right bank about $27 \mathrm{~km}$ from the coast. The catchment is generally undulating, hilly and broken towards the coast and with a steep escarpment at the headwaters. In the vicinity of Umtata, the river flows through a wide plain with a flat gradient. Further downstream, the river is incised in a deep gorge. There are extensive plantations in the headwaters (DWAF, 1998).

\section{Geology}

The geology of the catchment area of any river is important when discussing the chemical composition of its water resources. The geology of the Umtata River Catchment is constituted by mudstones and sandstones of the Beaufort group from the headwaters to about $30 \mathrm{~km}$ from the coast, and thence, by shales, mudstones and sandstones of the Ecca group, with exposures of dolerite intrusions mostly in the higher lying areas. There are scattered deposits of alluvium in some valleys. Soils in the catchment are moderate to deep and vary between sandy loams in the upper half to clayey loam in the downstream half (Du Preez and Jonas, 1983; DWAF, 1998).

The major types of soils found in the Transkei where the river catchment is located are solonetzic or alkaline soils; podsolic soils; Laterite Yellow Earths; and lithological and related soils (Van der Merwe, 1962). The parent rock for the solonetzic soils is sandstone and shale with dolerite intrusions (Du Preez and Jonas, 1983). This soil is poor in nitrogen but rich in lime, magnesium and potssium with a comparatively low availability of phosphate (Du Preez and Jonas, 1983).
The podsolic soils group is divided into three separate regions. The first region is the highveld prairie, which consists chiefly of sedimentary rocks in which dolerite intrusions sometimes occur. The typical soil is well developed and deep. It consists of a crumbly sandy loam and the substratum is greatly clay with foundations of more compact clay (Du Preez and Jonas, 1983). The second region is the semi-coastal region. The surface soil consists of a sandy loam with a layer of ferrugineous (derived from granite) concretions but not cemented (Du Preez and Jonas, 1983). The substratum is dense, impervious thin clay, which gradually merges with unweathered rock. In spite of its well-developed layers, this soil type is remarkably shallow. The third is the coastal region. The geological formation is sedimentary rock with dolorite intrusions and granite (Du Preez and Jonas, 1983). The surface is well developed but because of the steep topography there is accumulation of material in the subsoil. The well-developed soil consists of a crumbly, sandy loam resting on a layer of small round densely packed ferruginous concretions, underlain by a compact impervious clayey material (Du Preez and Jonas, 1983). The sandy soils vary from fairly acid to extremely acid. They are low in lime, magnesium, available phosphate and nitrogen but fairly high in potassium (Du Preez and Jonas, 1983). The red soils derived from dolerite contain an appreciable amount of nitrogen and potassium but are poor in lime and available phosphate.

The lateric yellow earths consist of basic igneous and sedimentary rocks. The well-developed yellow earths consist of a dark brown, crumbly clay surface soil with yellowish-brown crumbly clay subsoil (Du Preez and Jonas, 1983). The yellow earth is very acid and contains little lime and available phosphate while potassium and nitrogen are fairly high (Du Preez and Jonas, 1983).

The lithological type soils consist of basalt and quartzite (Du Preez and Jonas, 1983). The soil is poor in the various plant nutrients. The soils of the mountain region are generally poorly developed and shallow. Deep soil is found in the valleys only or on the gentle slopes. 


\section{Materials and methods}

\section{Sampling sites}

The location of the ten chosen sites along the Umtata River is shown in Fig. 1. The sampling sites were chosen to reflect different activities in the catchment - upstream, midstream and downstream which may affect the water quality situation in the river.

As the source of the river was not accessible, $\mathrm{S} 1$ was the closest accessible site to the source and was chosen as the reference site. $\mathrm{S} 1$ and $\mathrm{S} 2$ were upstream of the river. $\mathrm{S} 1$ was supposed to be pristine. However, there are three plantation locations located upstream of this site which impact on the river water quality. S2 was downstream from Tabase location (an informal settlement) and was chosen to monitor the impact of the informal settlement on the river water quality. Sites S3 to S5 are located along the mid-section of the river. Sample point S4 is in Umtata Dam with S5 further downstream (S3 was upstream of the dam and has an impact from Kanbi informal settlement, located near the bank). Water from Umtata Dam is treated and supplied to all parts of Umtata. These sites were chosen so as to ascertain the quality of the water from the dam (S4) and to note any change in water quality downstream of the dam (S5). Sites S6 to $\mathrm{S} 10$ are downstream. S6 is downstream of Pola Park location (a peri-urban settlement in Umtata town) and the site was chosen to establish the effect of runoff from this settlement on the river water quality. S7 is at Norwood Bridge, downstream of the Umtata City centre. There is also a rubbish dump upstream of this site. The urban runoff and leachates from the rubbish dump seeping into the river could adversely affect its quality at this site. Site S8 is downstream of the Umtata Sewage Works effluent discharge point. The impact of the sewage discharge on the river was monitored at this site. Site S9 is at Tipini location, another peri-urban settlement located on the river-bank. At this site, a large rubbish dump is located. It is worth mentioning that all the informal settlements are located on steep slopes close to the river that could greatly increase their impact on the river water quality. Site $\mathrm{S} 10$ is at the First Fall further down the river. Seasonal samples were taken bi-weekly between May 1999 and April 2000 to evaluate seasonal variations in water quality.

Before sampling for chemical analyses, sample bottles were cleaned by soaking them in detergent for $24 \mathrm{~h}$, followed by rinsing with tap water until free of detergent, then rinsed with $5 \%$ nitric acid and then thoroughly with distilled-deionised water (DWAF, 1992; Quality of Domestic Water Supplies, 1998). About 1 I of water samples for chemical analyses were collected from each sampling site according to the standard procedures described in DWAF's sampling guide(DWAF, 1992; Quality of Domestic Water Supplies, 1998). The samples were acidified with $5 \mathrm{ml}$ conc. $\mathrm{HNO}_{3}$. After collection the samples were placed in cooler boxes with ice bags whilst being transported to the laboratory and kept at about $4^{\circ} \mathrm{C}$ until analysed. All chemical analyses were done at least in duplicate.

\section{Physico-chemical analyses}

The $\mathrm{pH}$ of the water was determined on-site with a $\mathrm{pH} 330$ meter supplied by Merck NT Laboratory Pty Ltd. Total hardness was determined in the laboratory using the standard EDTA titration (Basset et. al., 1978; Van Loon, 1982). The acidified water samples (after filtration with the $45 \mu \mathrm{m}$ Whatman filter paper) was
TABLE 1

Levels of $\mathrm{pH}$ and total hardness in the Umtata River

\begin{tabular}{|c|c|c|c|}
$\mid 2$ & \multicolumn{2}{c|}{ Total hardness $\left(\mathrm{mg} \mathrm{CaCO}_{3} /\right.$ I) } \\
\cline { 2 - 4 } Mean \pm S.D. & Range & Mean \pm S.D. & Range \\
\hline $7.5 \pm 0.7$ & $6.6-8.8$ & $12.9 \pm 8.6$ & $0-21.5$ \\
$7.4 \pm 0.6$ & $6.6-8.5$ & $20.1 \pm 6.5$ & $0-27.2$ \\
$7.4 \pm 0.5$ & $6.7-8.3$ & $22.4 \pm 7.5$ & $11.5-43.7$ \\
$7.6 \pm 0.5$ & $6.9-8.7$ & $22.3 \pm 7.0$ & $8.6-43.0$ \\
$7.7 \pm 0.6$ & $6.3-8.7$ & $30.1 \pm 14.2$ & $15.7-64.5$ \\
$7.6 \pm 0.6$ & $6.1-8.7$ & $38.1 \pm 26.2$ & $7.9-105.3$ \\
$7.7 \pm 0.6$ & $6.5-8.5$ & $41.1 \pm 27.1$ & $19.3-104.6$ \\
$7.6 \pm 0.6$ & $6.8-8.9$ & $61.4 \pm 30.2$ & $20.1-135.5$ \\
$7.6 \pm 0.6$ & $6.4-8.5$ & $50.2 \pm 40.6$ & $20.7-159.9$ \\
$7.7 \pm 0.6$ & $6.5-8.7$ & $57.8 \pm 58.2$ & $19.3-213.7$ \\
\hline
\end{tabular}

- S10 are sampling sites

D. - Standard deviation

concentrated by complexing the metals with suitable ligands and extracting them from water samples with suitable solvents (Fries and Getrost, 1977). The metals were then determined by standard spectrometric methods (Fries and Getrost, 1977; DWAF, 1992). For quality control, water samples were spiked with known amounts of $\mathrm{ZnSO}_{4} .7 \mathrm{H}_{2} \mathrm{O}, \mathrm{PbNO}_{3}$ and $\mathrm{Cd}\left(\mathrm{NO}_{3}\right)_{2}$, respectively and the recovery of $\mathrm{Zn}, \mathrm{Cd}, \mathrm{Mn}$ and $\mathrm{Pb}$ was measured using the above standard procedures (Fries and Getrost, 1977; DWAF, 1992). Quality assurance studies were done in triplicate. Statistical calculations were done using Microsoft Excel.

\section{Results and discussion}

The percentage recoveries obtained for representative cations were: $\mathrm{Cd}, 74 \pm 5 \% ; \mathrm{Pb}, 85 \pm 6 \% ; \mathrm{Zn}, 77.7 \pm 7 \%$ and $\mathrm{Mn}, 93 \pm 3 \%$, which validate the experimental procedures used for the chemical analysis.

The mean $\mathrm{pH}$ values of water samples in the river varied between 7.4 and 7.7 (Table 1) at all the sites and fall within the Target Water Quality Range (TWQR) for $\mathrm{pH}$ in water for domestic use (6 to 9) (DWAF, 1996a). Since pH affects the solubility and toxicity of metals in the aquatic ecosystems, this $\mathrm{pH}$ range was used to access the metal toxicities in Umtata River for the use of the aquatic ecosystem.

The mean concentrations of water hardness in the river varied between $12.9 \mathrm{mg} \mathrm{CaCO} / /$ to $61.4 \mathrm{mg} \mathrm{CaCO}_{3} / \mathrm{l}$ (Table 1), which relates to soft and moderately soft water (DWAF, 1996a, Quality of Domestic Water Supplies, 1998) and the concentration was lowest at Site $\mathrm{S} 1$. Because the toxicities of $\mathrm{Pb}$ and $\mathrm{Cd}$ in the aquatic ecosystem varied with water hardness, the toxicities of these metals in the Umtata River were assessed in conjunction with the total hardness values of the river.

The results of the one-year measurement campaign of metals in the river are presented in Fig. 2 to 7. The mean levels of $\mathrm{Al}$ in the river varied between 0.22 and $0.36 \mathrm{mg} / \mathrm{l}$ in the river (Fig. 2) and were higher than the TWQR for $\mathrm{Al}$ in domestic water supply ( 0 to $0.15 \mathrm{mg} / \mathrm{l}$ ) (DWAF, 1996a). Based on these guidelines, direct use of water from the river without treatment may aggravate poor health of sensitive groups, for example people with kidney disease (DWAF 1996a; Savory and Wills, 1991). The tentative SA guidelines 


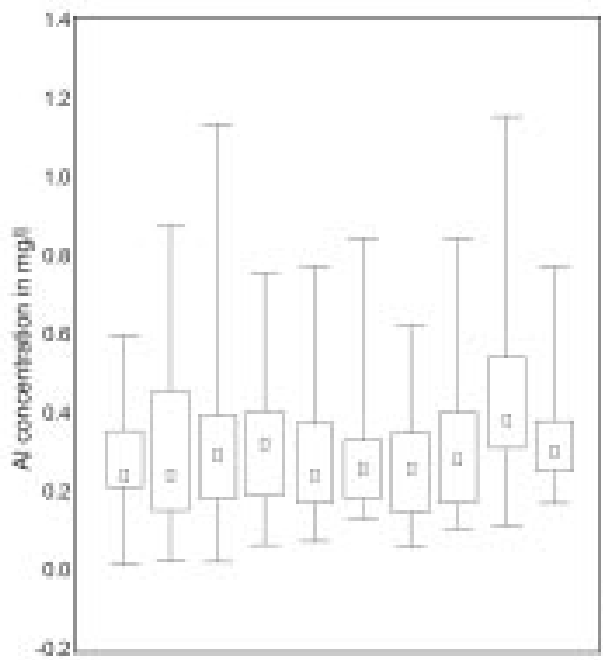

$\begin{array}{lllllllllll}31 & 82 & 59 & 94 & 55 & 96 & 97 & \text { s4 } & 59 & 518\end{array}$

Figure 2

Box and whisker plot for Al vs. sampling sites in Umtata River

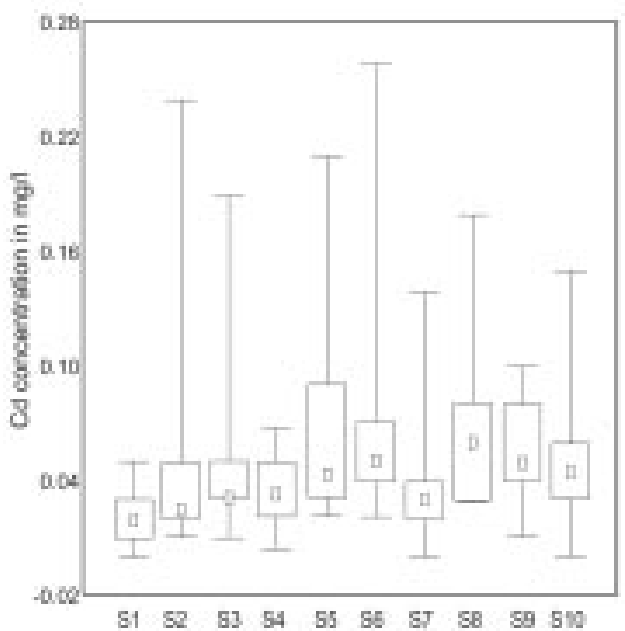

Figure 3

Box and whisker plot for Cd vs. sampling sites in Umtata River

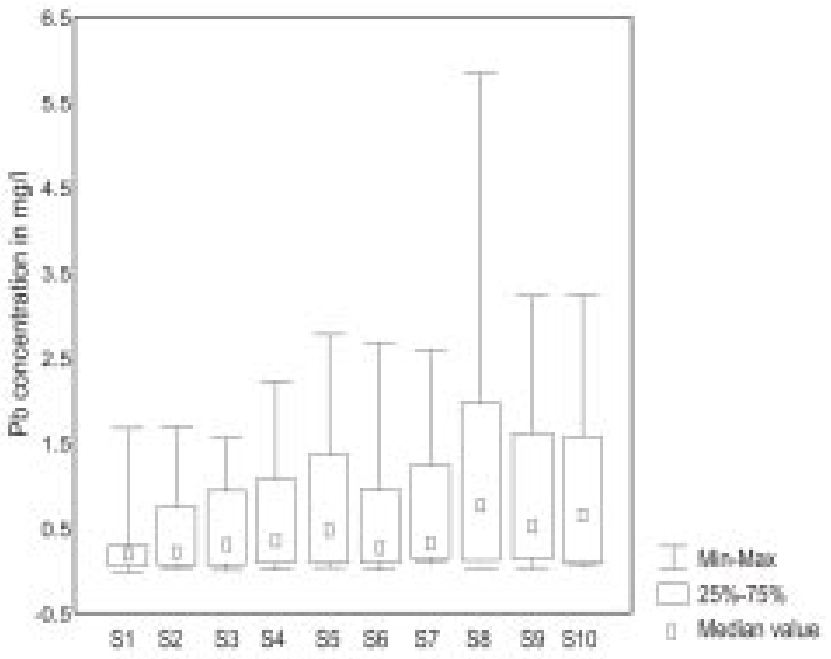

Figure 4

Box and whisker plot for Pb vs. sampling sites in Umtata River

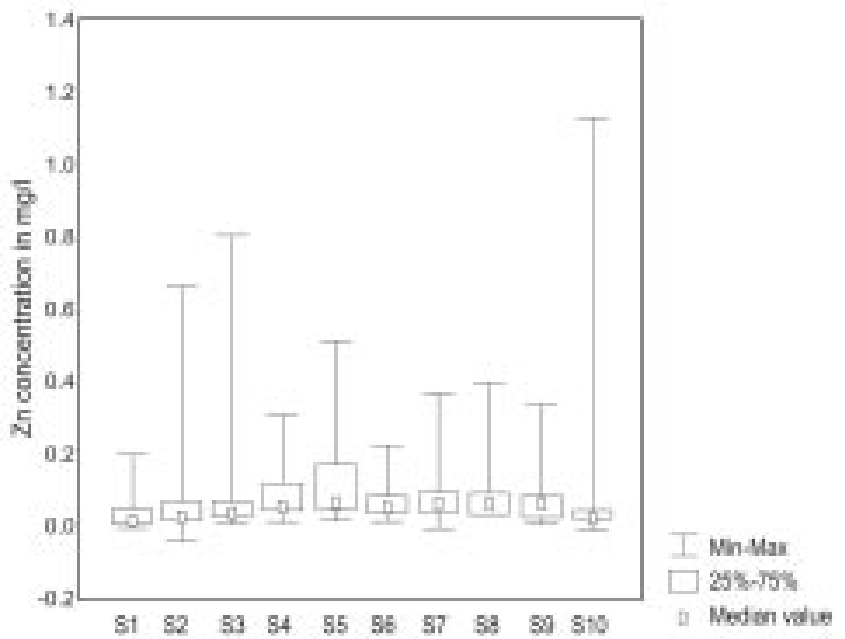

Figure 5

Box and whisker plot for Zn vs. sampling sites in Umtata River

water that will be used for livestock watering and irrigation is 0 to $10 \mu \mathrm{g} / \mathrm{l}$ (DWAF, 1996c). This level is also exceeded in the river and the use of water from the river to feed livestock will be detrimental to the health of livestock and the water will not be suitable for irrigation, though it is rarely practised in the catchment. The TWQR for Cd in water for the aquatic ecosystem is $0.15 \mu \mathrm{g} / \mathrm{l}$ in soft water and $0.25 \mu \mathrm{g} / \mathrm{l}$ in moderately soft water (DWAF, 1996b) and these values were exceeded in the Umtata River. Therefore the water will not be suitable for use by the aquatic ecosystem. There is no TWQR for Cd in water for recreational use (DWAF, 1996c, 1996e). The probable sources of $\mathrm{Cd}$ in the catchment are from natural sources due to geology of the catchment soil (DWAF 1996b), and from runoff from agricultural soils where phosphate fertilisers are used as $\mathrm{Cd}$ is a common impurity in phosphate fertilisers (Stoeppler, 1991). Other probable sources include leachates from nickel-cadmium based batteries and cadmiumplated items (Hutton et al., 1987; Stoeppler, 1991) that are disposed at the refuse dumps by the rural communities.

The mean $\mathrm{Pb}$ levels in the river ranged from $0.24 \mathrm{mg} / \mathrm{l}$ to $1.11 \mathrm{mg} / \mathrm{l}$ and the $\mathrm{Pb}$ levels were lowest at the reference site (S1) 


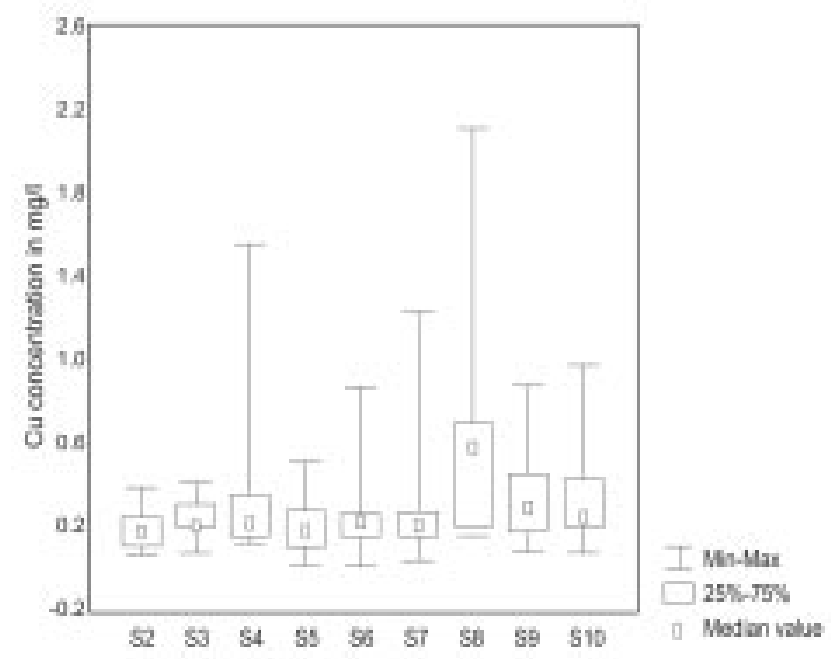

Figure 6

Box and whisker plot for Cu vs. sampling sites in Umtata River

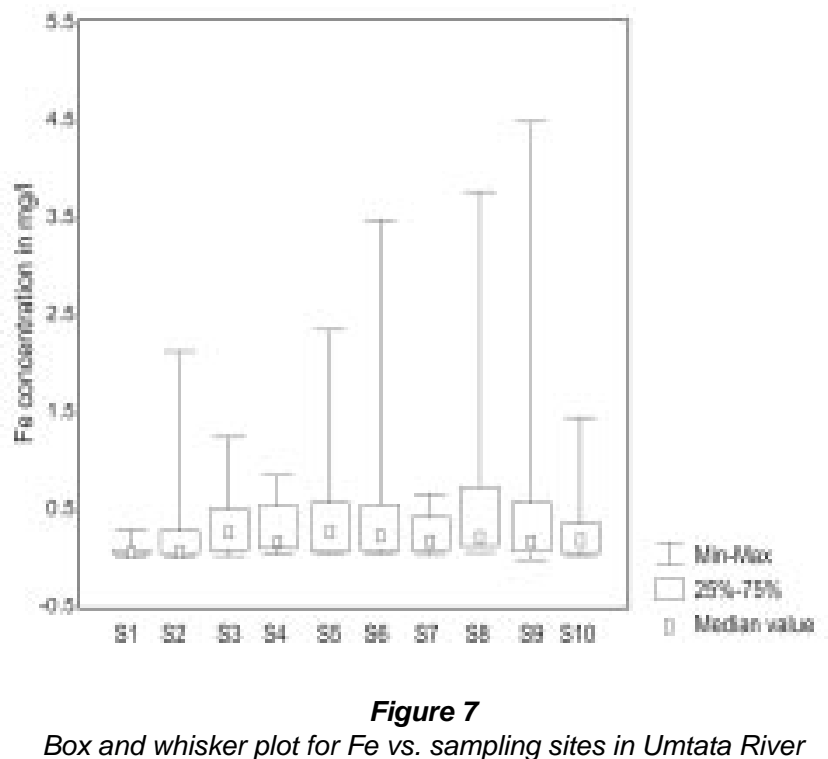

(Fig. 4). The TWQR for $\mathrm{Pb}$ in water for domestic use is 0 to $10 \mu \mathrm{g} / \mathrm{l}$ (DWAF, 1996a). At levels >100 $\mu \mathrm{g} / \mathrm{l}$, possible neurological damage in foetuses and young children may occur (DWAF, 1996a). These levels were exceeded in the river and the direct use of water from the river for domestic use without treatment could be detrimental to pregnant women and young children in the vicinity of the catchment. The TWQR for $\mathrm{Pb}$ in water for use by the aquatic ecosystem is $0.2 \mu \mathrm{g} / \mathrm{l}$ in soft water and $0.5 \mu \mathrm{g} / \mathrm{l}$ in moderately soft water (DWAF, 1996b). Chronic effects occur at levels of $0.5 \mathrm{~g} / \mathrm{l}$ (soft water) and >1.0 $\mu \mathrm{g} / \mathrm{l}$ (medium water) (DWAF, 1996b). These levels were exceeded in the river and therefore the river water would not be suitable for the maintenance of the aquatic ecosystem. The TWQR for $\mathrm{Pb}$ in water for livestock watering $(0.1 \mathrm{mg} / \mathrm{l})$ (DWAF, 1996c) was also exceeded in the river water. Volume 5 of the SA Water Quality Guidelines (DWAF, 1996d) states that "adverse chronic effects may occur at 0.5 to $1.0 \mathrm{mg} / \mathrm{l} \mathrm{Pb}$ ". The TWQR for $\mathrm{Pb}$ in water that will be used for irrigation is 0 to 0.2 $\mathrm{mg} / \mathrm{l}(1996 \mathrm{c})$. These levels were exceeded in the river water and the water will not be suitable for irrigation. There is no TWQR for $\mathrm{Pb}$ in water for recreational use (DWAF, 1996c, 1996e). Possible

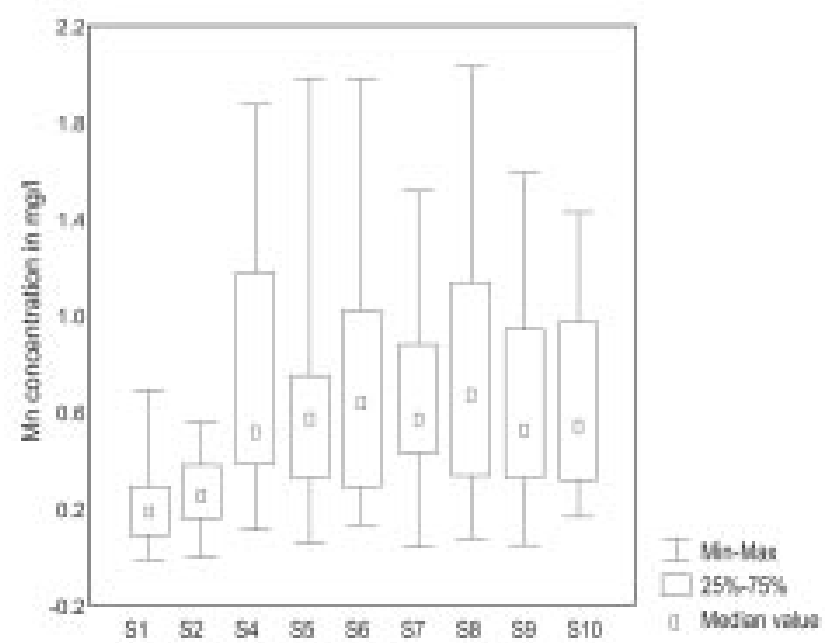

Figure 8

Box and whisker plot for Mn vs. sampling sites in Umtata River

sources of $\mathrm{Pb}$ in the catchment could be from the geology of the cathment, from sewage effluent discharge, from rural and urban runoff and from seepage from waste sites.

Mean levels of $\mathrm{Zn}$ in the river ranged from $0.07 \mathrm{mg} / \mathrm{l}$ to 0.12 $\mathrm{mg} / \mathrm{l}$ for all the sites (Fig. 5). The TWQR for $\mathrm{Zn}$ in water for domestic supply is $3 \mathrm{mg} / \mathrm{l}$ (DWAF, 1996a; Quality of Domestic Water Supplies, 1998) and should not be a problem in the river if the water is used for domestic purposes. However, $\mathrm{Zn}$ could be a problem in water for other uses, for example, for the use of aquatic ecosystems (DWAF, 1996b). The TWQR for $\mathrm{Zn}$ in water for the use of aquatic ecosystem is $2 \mu \mathrm{g} / \mathrm{l}$. This limit was exceeded in the river. Thus the river water will not be suitable for the maintenance of the aquatic ecosystem. The TWQR for $\mathrm{Zn}$ in water for irrigation is 0 to $1 \mathrm{mg} / \mathrm{l}$ and the TWQR for $\mathrm{Zn}$ in water for livestock watering is 0 to $20 \mathrm{mg} / \mathrm{l}$ (DWAF, 1996c). The Zn levels fell within these ranges therefore $\mathrm{Zn}$ will not be a problem in the river water if used for irrigation or livestock watering. There is no TWQR for $\mathrm{Zn}$ in water for recreational uses (DWAF, 1996c, 1996e).

Mean levels of $\mathrm{Cu}$ in the river varied between $0.10 \mathrm{mg} / \mathrm{l}$ to 0.53 $\mathrm{mg} / \mathrm{l}$ for all the sites (Fig. 6). The SA guideline for $\mathrm{Cu}$ in domestic water supply is 0 to $1.0 \mathrm{mg} / \mathrm{l}$ (DWAF, 1996a). These values were not exceeded in the river and therefore $\mathrm{Cu}$ is not supposed to be a problem for the domestic use of water from the river (DWAF, 1996a). The TWQR for Cu in water for use of the aquatic ecosystem ranges from $0.3 \mu \mathrm{g} / \mathrm{l}$ in water that is soft and $0.8 \mu \mathrm{g} / \mathrm{l}$ in water that is moderately soft (DWAF, 1996b). These limits were exceeded in the river and therefore will make the river unsuitable for the maintenance of the aquatic ecosystem. The TWQR for $\mathrm{Cu}$ in water for livestock watering is 0 to $5 \mathrm{mg} / \mathrm{l}$ and the adverse chronic effect may occur at 1 to $10 \mathrm{mg} / \mathrm{Cu}$, depending on the livestock (DWAF, 1996d). These levels were not exceeded in the river therefore $\mathrm{Cu}$ will not be a problem in the river water if used for livestock watering. The TWQR for $\mathrm{Cu}$ in water that will be used for irrigation is 0 to $0.2 \mathrm{mg} / \mathrm{l}$ (DWAF, 1996c) and therefore $\mathrm{Cu}$ is not supposed to be a problem for the irrigational use of water from the river. There is no TWQR for $\mathrm{Cu}$ in water for recreational use (DWAF, 1996c, 1996e).

Mean levels of $\mathrm{Fe}$ in the river varied between $0.10 \mathrm{mg} / \mathrm{l}$ and $4.47 \mathrm{mg} / \mathrm{l}$ (Fig. 7) and between $0.16 \mathrm{mg} / \mathrm{l}$ and $2.04 \mathrm{mg} / \mathrm{l}$ for $\mathrm{Mn}$ (Fig. 8). The SA guideline for Fe is $0.1 \mathrm{mg} / \mathrm{l}$ and for $\mathrm{Mn}$ is 0.05 $\mathrm{mg} / \mathrm{l}$ in water for domestic use (DWAF, 1996a). These limits were exceeded in the river at most of the sites. The implication of this is 
that the water from the river may have taste and other aesthetic problems (DWAF, 1996a). The TWQR for Fe and Mn in water for livestock watering is 0 to $10 \mathrm{mg} / \mathrm{l}$ (DWAF, 1996c). These levels were not exceeded in the water and $\mathrm{Fe}$ and $\mathrm{Mn}$ will not be a problem in the river water if it is used for livestock watering. There is no TWQR for Fe in water for the aquatic ecosystem use but the TWQR for Mn for the same use is $0.18 \mathrm{mg} / \mathrm{l}$ (DWAF, 1996c). This level was exceeded in the river therefore the river will not be suitable for the maintenance of the aquatic ecosystem. The TWQR for Fe and $\mathrm{Mn}$ in water that will be used for irrigation are 0 to $5 \mathrm{mg} / \mathrm{l}$ and 0 to $0.02 \mathrm{mg} / \mathrm{l}$, respectively (DWAF, 1996c). The TWQR for Mn was exceeded in the river therefore Mn will pose a problem if the river water is used for irrigation. There are no TWQRs for $\mathrm{Fe}$ and $\mathrm{Mn}$ in water for recreational use (DWAF, 1996c, e).

The high levels of metals in the river give cause for concern because the people's health and the "health" of the ecosystem are at stake. Generally the sources of metal pollution in the catchment appear to be diffuse, which include rural, urban as well as agricultural runoff and point sources in the catchment (i.e. Umtata Sewage Works). There could be contributions from natural sources.

Relevant authorities should attend to the management of metal pollution in the river. The Umtata Sewage Works has been identified as a major pollution source of the river. After the promulgation of the New National Water Act (Act 36 of 1998), the Umtata Sewage Works was given a 5-year permit to discharge effluent in 1999. Currently the Sewage Works seems to do very little in the way of 'treatment' and people's health is at stake and so are our water resources and the health of the ecosystem.

\section{Conclusion}

Dissolved $\mathrm{Al}, \mathrm{Cd}, \mathrm{Pb}, \mathrm{Cu}, \mathrm{Zn}, \mathrm{Fe}$ and $\mathrm{Mn}$ in Umtata River have been determined in this study. High levels of $\mathrm{Al}, \mathrm{Cd}, \mathrm{Pb}, \mathrm{Zn}$ and $\mathrm{Cu}$ were observed, which may affect the "health" of the aquatic ecosystem. The high levels of $\mathrm{Al}, \mathrm{Cd}$ and $\mathrm{Pb}$ may have a detrimental effect on the health of the rural community in the vicinity of the river catchment that uses the river water directly for domestic use without treatment. The Umtata Sewage Works is a major pollution source of the river and needs to be upgraded to improve its treatment performance.

\section{Acknowledgement}

The authors would like to thank the Water Research Commission (WRC) for funding this research.

\section{References}

ALABASTER JS and LLOYD R (1980) Water Quality Criteria for Fish (2nd edn.). London: Butterworths.

ALFERY AC, LEGENDRE GR and KAEHNY WD (1976) The dialysis encephalophathy syndrome. Possible aluminum intoxication. N. Engl. J. Med. 294 184-188.

ASAMIT (1974) Environmental pollution by cadmium and zinc discharged from a Braun tube factory. Ibaraki Daigaku Nogakubu Gakujutsu Hokakn 22 19-23.

BASSET J, DENNY RC, JEFFERY, GH and MENDHAM J (eds.) (1978) Vogel's Textbook of Quantitative Inorganic Analysis ( ${ }^{\text {th }}$ edn). Longman Group Limited, London.

DEAN JG, BOSQUI FL and LANOUETTE VH (1972) Removing heavy metals from waste water. Environ. Sci. Technol. 6 518-522.

DEPARTMENT OF WATER AFFAIRS \& FORESTRY (1992)Analytical Methods Manual, TR151. DWAF, Pretoria.

DEPARTMENT OF WATER AFFAIRS \& FORESTRY (1996a) Water Quality Guidelines, Domestic Use. Volume 1 (2nd edn.), DWAF, Pretoria.
DEPARTMENT OF WATER AFFAIRS \& FORESTRY (1996b) Water Quality Guidelines, Aquatic Ecosystem Use. Volume 7 (1st edn.), DWAF, Pretoria.

DEPARTMENT OF WATER AFFAIRS \& FORESTRY (1996c) South African Water Quality Guidelines, Field Guide. Volume 8 (1st edn.), DWAF, Pretoria.

DEPARTMENT OF WATER AFFAIRS \& FORESTRY (1996d) South African Water Quality Guidelines, Agricultural Use: Livestock Watering. Volume 5 (2nd edn.), DWAF, Pretoria.

DEPARTMENT OF WATER AFFAIRS \& FORESTRY (1996e) South African Water Quality Guidelines, Recreational Use. Volume 2 (2nd edn.), DWAF, Pretoria.

DEPARTMENT OF WATER AFFAIRS \& FORESTRY (1998) Umtata River Catchment Preliminary Framework for the Development of an Integrated Catchment Management Plan. Report by Ninham Shand Consulting Engineers. DWAF, Pretoria.

DU PREEZ AL and JONAS PMM (1983) Chemical Composition of Transkei River and Dam Water. Department of Chemistry, University of Transkei.

FIELD RA and LAGER TA (1975) Urban runoff pollution control-stateof-the-art. J. Environ. Eng. Div. ASCE 101 (EE-1) 107-125.

FISCHER AB (1987) Mutagenic effects of cadmium alone and in combination with antimutagenic selenite. Proc. $6^{\text {th }}$ Int. Conf. on Heavy Metals in the Environment, New Orleans, Vol. 2. CEP Consultants Ltd, Edinburgh. 112-114.

FRIBERG L, ELINDER CG, KJELLSTROEM T and NORDBERG GF (eds.) (1986a) Cadmium and Health: A Toxicological and Epidemiological Appraisal. Volume 11, Effects and Response. CRC Press, Boca Raton, Florida.

FRIBERG L, KJELLSTROEM T and NORDBERG GF (1986b). In: FRIBERG L, NORDBERG GF and VONK VB (eds.) Handbook on the Toxicology of Metals, Volume 11. Elsevier, Amsterdam. New York. Oxford. 130-184.

FRIES J and GETROST H (1977) Organic Reagents for Trace Analysis. E. Merck, Darmstadt.

HERBER FRM, VERSCHOOR MA AND WIBOWO AAE (1988) A review of the kinetics and kidney effects of Cadmium - Recent epidemiological studies. In: Hutzinger $\mathrm{O}$ and Safe $\mathrm{SH}$ (eds.) Environmental Toxins, Volume 2, Cadmium (Vol. eds.: Stoeppler M and Piscator M). Springer, Berlin-Heidelberg. New York-LondonParis-Tokyo. 115-133.

HEINRICH U (1988) Carcinogenicity of cadmium - Overview of experimental and epidemiological results and their influence on recommendations for maximum concentrations in the occupational area. In: Hutzinger $\mathrm{O}$ and Safe $\mathrm{SH}$ (eds.) Environmental Toxins, Volume 2, Cadmium. (Vol. eds.: Stoeppler M and Piscator M). Springer, Berlin-Heidelberg. New York-London-Paris-Tokyo. 13-15.

HEITFELD KH and SCHOTTLER U (1973) Verackert wohin? Kontamination des Wassers in Bereich von Abfallhalden durch spurenmettale. Umwelt 1 57-58.

HUTTON M, CHANEY RL, KRISHNA CR, MURTI M, OLADE A and PAGE AL (1987) Group Report. In: Hutchinson TC and Meema KM (eds.) Lead, Mercury, Cadmiun and Arsenic in the Environment. John Wiley, New York. 35-41.

KAZANTZIS G(1987) The mutagenic and carcinogenic effect of cadmium. An update. J. Toxicol. Environ. Chem. 15 83-100.

KJELLSTROEM T (1986) Itai-itai Disease. In: Friberg L, Elinder CG, Kjellstroem T and Nordberg GF (eds): Cadmium and Health: A Toxicological and Epidemiological Appraisal, Volume 11, Effects of Response. CRC Press, Boca Raton, Florida. 257-290.

LANSDOWN R (1986) Lead, intelligence attainment and behavior. In: Lansdown R and Yule W (eds.) The Lead Debate. Croom Helm, London-Sydney. 235-270.

LEWIS TE (1989) Chemistry and Toxicity of Aluminum. Lewis Publishers, Chelsea.

MERIAN E (ed.) (1991) Metals and their Compounds in the Environment. Occurrence Analysis and Biological Relevance. UCH, WeinheimNew York-Basel-Cambridge.

NEEDLEMAN HL (1987) Low level lead exposure and children's intelligence: A quantitative and critical review of modern studies. Proc. 6th Int. Conf. on Heavy Metals in the Environment, New Orleans. Volume 1. CEP Consultants Ltd., Edinburg. 1-8. 
PRATER BE (1975) The metal content and characteristics of Steework's effluents discharging to the Tees estuary. Water Pollut. Control 74 63-78.

PREUSS E and KOLLMANN H (1974) Metallgehalte in Klärschlammen. Naturwissenschafter 61 270-274

QUALITY OF DOMESTIC WATER SUPPLIES (1998) Volume 1: Assessment Guide (2nd edn.). Department of Water Affairs and Forestry, Department of Health and Water Research Commission, Pretoria.

RADUNOVIC A and BRADBURY MWB (1993) Determination of aluminum in different tissues of the rat by atomic absorption spectrometry with electrothermal atomization. Analyst 118 533-536.

RAO JD and SAXENA AB (1981) Acute toxicity of mercury, zinc, lead, cadmium, manganese to the Chironomus sp. Int. J. Environ. Studies 16 225-226.

SARTOR JD, BOYD GB and AGANDY (1974) Water Pollution Aspects of Street Surface Contaminants.

SAVORY J and WILLS MR (1991) Aluminum. In: Merian E (ed.) Metals and their Compounds in the Environment. Occurrence, Analysis and Biological Relevance. VCH Weinheim-New York-Basel-Cambridge.

SCHEINBERG HI (1991) Copper. In: Merian E (ed.) Metals and their Compounds in the Environment: Occurrence, Analyses and Biological Relevance. VCH, New York. 803-851.
SKIDMORE JF (1964) Toxicity of zinc compounds in aquatic animals with special reference to fish. Q. Rev. Biol. 39 227-248.

SPEAR PA (1981)Zinc in the Aquatic Environment; Chemistry, Distribution And Toxicology. National Research Council of Canada, Associate Committee on Scientific Criteria for Environmental Quality. Report NRCC No 17589. Ottawa.

STOEPPLER M (1991) Cadmium. In: Merian E (ed.) Metals and their Compounds in the Environment: Occurrence, Analyses and Biological Relevance. VCH, New York, 803-851.

TSUCHIYA K (1978) Cadmium Studies in Japan - A Review. Kodansha Ltd. Tokyo-Elsevier/North Holland Biomedical Press, AmsterdamNew York- Oxford.

UNITEDSTATESENVIRONMENTALPROTECTIONAGENCY (1986) Quality Criteria for Water - 1986. United Environmental Protection Agency office of Water Regulations and Standards. Washington DC, 20460.

VAN DER MERWE CR (1962) Soil Group and Subgroups of South Africa. Div. of Chem. Services, Dept. of Agriculture.

VAN LOON JC (1982) Chemical Analysis of Inorganic Constituent of Water. CRC Press.

WOODWORTH JC and PASCOE V (1982) Cadmium toxicity to rainbow trout, Salmon gairdneri Richardson. A study of eggs and alevins. J. Fish. Biol. 21 47-57. 
